\title{
ANALISIS KINERJA REALISASI ANGGARAN PENDAPATAN DAN BELANJA DAERAH SERTA POTENSI PENDAPATAN ASLI DAERAH PADA KABUPATEN MINAHASA UTARA
}

\author{
Nathania Ch. E. Sasuwuk ${ }^{1}$ \\ Jullie J. Sondakh ${ }^{2}$ \\ Jessy D. L. Warongan ${ }^{3}$ \\ ${ }^{1,2,3}$ Faculty of Economics and Business, Accounting Departement \\ Sam Ratulangi University of Manado
}

email : ${ }^{1}$ nathania940321@ gmail.com

julliesondakh@yahoo.com

j.jimarcus@gmail.com

\begin{abstract}
Realization of Regional Government budget (APBD) is one of measure instrument to see the implementation from policies and operationalization implementation of financial regional management for optimal actualization public services. Management potential of Local Revenue $(P A D)$ have to do with correct and appropriate in order to support the progress. The purpose of this research are to know and analyze the realization performance of regional government budget and district own source revenue potential at North Minahasa Region. The result of this research show the regional government budget of North Minahasa in terms of revenue considered good by looking from variance analyzes and tax effectiveness, expect from decentralization degree analyzes is not good enough or low. While for expense, from variance analyzes over all is good by looking at the budget are well controlled and the impact in the North Minahasa Region for having an surplus from the allocated budget, and for compatibility analyzes expenditure are effective because realization of the expense budget not over amount that has been planned. And for the Own Source Revenue Potential for 2016-2020 seen from tax regional income are 42,78\% while from regional retribution are 37,36\%. Keywords: performance, government, budget, Potential, Local Revenue
\end{abstract}

\section{PENDAHULUAN}

\section{Latar Belakang}

Realisasi Anggaran Pendapatan dan Belanja Daerah (APBD) merupakan salahsatu alat ukur untuk melihat implementasi dari kebijakan dan operasionalisasi pelaksanaan pengelolaan keuangan suatu daerah dalam upaya mewujudkan pelayanan publik yang optimal serta upaya dalam mendorong pembangunan ekonomi di daerah. Besarnya realisasi anggaran dan jenis belanjanya mengindikasikan besarnya komitmen dan keseriusan suatu pemerintah daerah pada aspek-aspek yang menjadi prioritas daerah.

Pengelolaan keuangan negara mengharuskan pertanggung jawaban dalam pengelolaan keuangan negara dilakukan dalam bentuk perhitungan anggaran negara/daerah sesuai dengan ketentuan perundang-undangan. Wujud laporan ini hanya menginformasikan aliran kas APBN/APBD sesuai dengan format anggaran yang disahkan oleh legislatif, tanpa menyertakan informasi tentang posisi kekayaan dan kewajiban pemerintah. Laporan tersebut selain memuat informasi yang terbatas, juga waktu penyampaiannya dalam perhitungan anggaran juga sangat rendah karena sistem akuntansi yang diselenggarakan belum didasarkan pada standar akuntansi dan tidak didukung oleh perangkat data dan proses yang memadai.

Menurut Undang-Undang Nomor 17 Tahun 2003, pada rancangan undang-undang atau peraturan daerah tentang laporan keuangan pemerintah pusat/daerah disertakan atau dilampirakan informasi tambahan mengenai kinerja instansi pemerintah, yakni prestasi yang berhasil dicapai oleh pengguna anggaran sehubungan dengan anggaran yang telah digunakan. Pengungkapan informasi tentang kinerja ini adalah relevan dengan perubahan paradigma penganggaran pemerintah yang 
ditetapkan dengan mengidentifikasi secara jelas pengeluaran dari setiap kegiatan dan hasil dari setiap program. Untuk keperluan tersebut, perlu disusun sistem akuntabilitas kinerja instansi pemerintah yang terintegrasi dengan sistem perencanaan strategis, sistem pengganggaran, dan sistem akuntansi pemerintah.

Pengelolaan keuangan dalam suatu daerah sangatlah penting dilakukan oleh Pemerintah. Kinerja dalam merealisasikan anggaran pendapatan dan belanja daerah jika dilakukan dengan baik dan benar maka akan menghasilkan perkembangan pembangunan bagi daerah, serta dapat mensejahterakan masyarakat. Selain itu juga harus meningkatkan pengelolaan potensi PAD dengan benar dan sesuai agar dapat menunjang pendapatan untuk perkembangan kabupaten/kota yang ada.

Pemerintah Kabupaten Minahasa Utara adalah Kabupaten yang terletak di antara dua kota yaitu Manado dan Bitung. Kabupaten Minahasa Utara memiliki banyak kekayaan alam baik dari segi pariwisata, pertanian, perikanan dan kelautan serta pertambangan, potensi daerah ini dapat membantu pemerintah dalam meningkatkan PAD jika di kelola dengan baik dan benar. Ini juga dapat menjadi tantangan bagi pemerintah daerah dalam penyusunan APBD yang baik dan benar sebagaimana yang tercantum dalam Peraturan Menteri Dalam Negeri No. 21 Tahun 2011 tentang perubahan kedua atas Permendagri No. 13 tahun 2006 tentang pengelolaan keuangan daerah, dan juga dapat merealisasikan anggaran sesuai dengan tujuan yang telah ditetapkan.

\section{Tujuan Penelitian}

Tujuan Penelitian ini adalah untuk mengetahui dan menganalisis kinerja realisasi pendapatan dan belanja PemerintahKabupaten Minahasa Utara tahun anggaran 2011-2015 serta mengetahui potensi pendapatan asli daerah Pemerintah Kabupaten Minahasa Utara pada tahun 2016-2020.

\section{TINJAUAN PUSTAKA}

\section{Akuntansi Sektor Publik}

Mahsun (2013:5) menyatakan, sektor publik seringkali dipahami sebagai segala sesuatu yang berhubungan dengan kepentingan umum dan penyediaan barang atau jasa kepada publik yang dibayar melalui pajak atau pendapatan negara lain yang diatur dengan hukum.

\section{Standar Akuntansi Pemerintah}

Standar Akuntansi Pemerintah (SAP) sesuai Peraturan Pemerintah No. 71 Tahun 2010 terdiri atas:

1. PSAP No. 1 tentang Penyajian Laporan Keuangan

2. PSAP No. 2 tentang Laporan Realisasi Anggaran

3. PSAP No. 3 tentang Laporan Arus Kas

4. PSAP No. 4 tentang Catatan Atas Laporan Keuangan

5. PSAP No. 5 tentang Akuntansi Persediaan

6. PSAP No. 6 tentang Akuntansi Investasi

7. PSAP No. 7 tentang Aset Tetap

8. PSAP No. 8 tentang Konstruksi dalam pengerjaan

9. PSAP No. 9 tentang Akuntansi Kewajiban

10. PSAP No. 10 tentang Koreksi Kesalahan, Perubahan Kebijakan Akuntansi dan Peristiwa Luar Biasa

11. PSAP No. 11 tentang Laporan Keuangan Konsolidasian.

12. PSAP No. 12 tentang Laporan Operasional

\section{Sistem Akuntansi Pemerintahan}

Dalam Peraturan Menteri Keuangan Nomor 262/PMK.05/2014, Sistem Akuntansi dan Pelaporan Keuangan Pusat (SiAP) adalah serangkaian prosedur manual maupun yang terkomputerisasi mulai dari pengumpulan data, pencatatan, pengiktisaran sampai dengan pelaporan posisi keuangan, dan operasi keuangan pada kementrian keuangan selaku BUN. 
Mahmudi (2011:223) menyatakan Sistem akuntansi Pemerintah Daerah (SAPD) adalah serangkaian prosedur manual maupun yang terkomputerisasi mulai dari pengumpulan data, pencatatan, pengiktisaran sampai dengan pelaporan posisi keuangan dan operasi Pemerintah Daerah

\section{Anggaran Pendapatan dan Belanja Daerah}

Permendagri No. 21 Tahun 2011 tentang Pedoman Pengelolaan Keuangan DaerahAnggaran Pendapatan Belanja Daerah (APBD) adalah rencana keuangan tahunan pemerintah daerah yang dibahas dan disetujui bersama oleh pemerintah daerah dan DPRD, dan ditetapkan dengan peraturan daerah.

Dikutip dalam Kemenkeu RI-DJPK Modul Perencanaan dan Penganggaran Daerah (2014:36) APBD merupakan wujud tahunan dari rencana jangka panjang daerah serta rencana jangka menengah yang dibuat dari visi dan misi kepala daerah. APBD dipersiapkan oleh pemerintah daerah, dibahas dan disetujui oleh Dewan Perwakilan Rakyat Daerah sehingga pada akhirnya merupakan produk hukum berupa peraturan daerah yang harus diikuti oleh segenap lembaga di daerah.

\section{Konsep Anggaran}

Mardiasmo (2009), menyatakan Penyusunan APBD merupakan proses penganggaran daerah yang secara konseptual terdiri atas formulasi kebijakan (budget policyformulation) dan perencanaan operasional anggaran (budget operation planning). Penyusunan Kebijakan Umum APBD (KUA) termasuk kategori formulasi kebijakan anggaran. Formulasi kebijakan anggaran berkaitan dengan analisis fiskal, sedang perencanaan operasional anggaran lebih ditentukan pada alokasi sumber daya keuangan.

\section{Pendapatan Daerah}

Dalam Peraturan Pemerintah No. 71 Tahun 2010 tentang Standar Akuntansi Pemerintahan, Pendapatan adalah semua penerimaan rekening atas kas umum negara/ daerah yang menambah ekuitas dana lancar dalam periode tahun anggaran yang bersangkutan yang menjadi hak pemerintah, dan tidak perlu dibayar kembali. Peraturan Menteri Dalam Negeri No. 21 Tahun 2011, mendefinisikan pendapatan sebagai hak pemerintah daerah yang diakui sebagai penambah nilai kekayaan bersih. Dari kedua definisi tersebut jelas terlihat bahwa pendapatan merupakan hak pemerintah yang menambah nilai ekuitas dana pemerintah. Kelompok pendapatan yang diterima oleh PPKD adalah sebagai berikut ; (1) Pendapatan asli daerah, (2) dana perimbangan, (3) lain-lain pendapatan daerah yang sah.

\section{Belanja Daerah}

Peraturan Menteri Dalam Negeri No. 21 Tahun 2011 menjelaskan belanja daerah adalah kewajiban pemerintah daerah yang diakui sebagai pengurang nilai kekayaan bersih. Belanja daerah meliputi semua pengeluaran dari rekening kas umum daerah yang mengurangi ekuitas dana lancar, yang merupakan kewajiban daerah dalam satu tahun anggaran yang tidak akan diperoleh pembayarannya kembali oleh daerah.

Menurut Permendagri No. 21 Tahun 2011, Kelompok Belanja terdiri dari:

a. Belanja tidak langsung

b. Belanja Langsung

\section{Kinerja Realisasi Anggaran Pendapatan dan Belanja Daerah}

Kinerja (performance) adalah gambaran mengenai tingkat pencapaian pelaksanaan suatu kegiatan/program/kebijakan dalam mewujudkan sasaran, tujuan, misi, dan visi organisasi yang tertuang dalam strategic planning suatu organisasi. Instilah kinerja sering digunakanuntuk menyebut prestasi atau tingkat keberhasilan individu maupun kelompok individu. Kinerja bisa diketahui hanya jika individu atau kelompok individu tersebut mempunyai kriteria keberhasilan yang telah ditetapkan. Kriteria keberhasilan ini berupa tujuan-tujuan atau target-target tertentu yang hendak dicapai. Tanpa ada tujuan atau target, kinerja seseorang atau organisasi tidak mungkin dapat diketahui karena tidak ada tolok ukutnya (Mahsun, et al. 2015:141). 


\section{Evaluasi Kinerja}

Evaluasi kinerja memberikan gambaran kepada penerima informasi mengenai nilai kinerja yang berhasil dicapai organisasi. Capaian kinerja organisasi dapat dinilai dengan skala pengukuran tertentu. Informasi capaian kinerja dapat dijadikan feedback dan reward-punishment, penilaian kemajuan organisasi dan dasar peningkatan kualitas pengambilan keputusan akuntabilitas. (Mahsun, et al. 2015:144).

\section{Menghitung Potensi Pendapatan Asli Daerah}

Menghitung Tingkat Efektivitas dan Efisiensi serta Daya Pajak (Murdiati, 2012)

1. Efektivitas

Efektivitas adalah mengukur hubungan antara hasil pungut suatu pajak dengan potensi pajak itu sendiri

2. Efisiensi

Efisiensi Mengukur bagian dari hasil pajak yang digunakan untuk menutup pemungutan pajak yang bersangkutan

Kriteria tingkat efektivitas maupun efisiensi menurut Kepmendagri Nomor 690.900.327 Tahun 1996 tentang Pedoman Penilaian Kinerja Keuangan ditetapkan sebagai berikut;

Tabel 2.2

Penilaian kinerja Keuangan

Penilaian Kinerja Keuangan

\begin{tabular}{lll}
\hline Tingkat Efisiensi & Presentase & Tingkat Eviktifitas \\
\hline Tidak Efisien & $>100 \%$ & Sangat Efektif \\
\hline Kurang Efisien & $90 \%-100 \%$ & Efektif \\
\hline Cukup Efisien & $80 \%-90 \%$ & Cukup Efektif \\
\hline Efisien & $60 \%-80 \%$ & Kurang Efektif \\
\hline Sangat Efisien & $<60 \%$ & Tidak Efektif \\
\hline \multicolumn{2}{c}{ Sumber: N. Komalig (2014) dalam Lengkong (2011) }
\end{tabular}

3. Daya pajak

Daya Pajak (Tax effort) adalah ratio antara penerima pajak dengan kapastian atau kemampuan bayar pajak di suatu daerah. Salah satu indikator yang dapat digunakan untuk mengetahui kemampuan membayar masyarakat adalah Produk Domestik Regional Bruto (PDRB)

\section{METODE PENELITIAN}

\section{Jenis Penelitian}

Kuncoro $(2013 ; 145)$ menjelaskan bahwa jenis data terdiri dari data kuantitatif dan data kualitatif.

1. Data Kualitatif adalah data-data yang disajikan dalam bentuk uraian yang tidak dapat diukur dalam skala numerik.

2. Data Kuantitatif adalah data-data yang disajikan dalam bentuk angka-angka yang dapat diukur dengan skala numerik.

Dalam penelitian ini penulis menggunakan kedua jenis data tersebut dalam penulisan skripsi ini, yaitu data kualitatif dalam hal ini berupa gambaran umum Kabupaten Minahasa Utara dan data kuantitatif adalah laporan realisasi anggaran pemerintah Kabupaten Minahasa Utara tahun anggaran 2011-2015 serta potensi pendapatan asli daerah tahun 2016-2020.

\section{Tempat dan Waktu Pelaksanaan}

Penelitian ini dilakukan pada Badan Pengelola Keuangan dan Barang Milik Daerah Kabupaten Minahasa Utara dan Dinas Pendapatan Minahasa Utara. Adapun penelitian ini akan dilakukan selama dua bulan. 


\section{Prosedur Penelitian}

Prosedur penelitian yang dilakukan adalah:

a. Peninjauan langsung (observasi), penulis langsung kelokasi dengan membawa surat pengantar penelitian penulisan skripsi dari fakultas untuk meminta persetujuan dari pihak tempat penelitian dalam hal ini Kepala Sub Bagian Umum BPK-BMD Kabupaten Minahasa Utara dan Sekretaris Dinas Pendaptan Kabupaten Minahasa Utara.

b. Wawancara, yaitu melakukan tatap muka dan Tanya jawab secara langsung dengan pihak-pihak yang bertanggungjawab pada masalah yang diteliti dalam hal ini Sekretaris dan Kepala Bidang Anggaran BPK-BMD Kabupaten Minahasa Utara serta Kepala Bidang Pajak Daerah Dinas Pendapatan Kabupaten Minahasa Utara.

c. Pengamatan prosedur-prosedur atau kebijakan-kebijakan yang dilakukan instansi pemerintah dalam melakukan realisasi anggaran pendapatan dan belanja daerah yang di amati dalam Laporan Realisasi Anggaran tahun 2011-2015

\section{Metode Pengumpulan Data}

Metode pengumpulan data yang dilakukan adalah:

1. Penelitian Lapangan

Studi lapangan adalah merupakan langkah-langkah pengumpulan data yang ditempuh penulis secara langsung dari lembaga pemerintahan yang menjadi objek penelitian dengan cara:

a. Wawancara dengan pimpinan/pejabat pemerintahan, wawancara ini merupakan teknik pengumpulan data yang dilakukan dengan bagian-bagian yang berkepentingan dan terlibat langsung dengan yang dibahas serta berhubungan dengan data yang diperlukan penulis.

b. Peninjauan langsung atau observasi langsung tentang system kerja, terutama yang berhubungan dengan proses penyusunan anggaran belanja daerah.

Pengamatan prosedur-prosedur atau kebijakan yang dilaksanakan oleh pemerintah Kabupaten Minahasa Utara

\section{Metode Analisis Data}

Metode analisis data yang digunakan adalah deskriptif dimana sifatnya menguraikan dan menggambarkan suatu data atau keadaan serta melukiskan atau menjelaskan sedemikian rupa sehingga dapat ditarik kesimpulan untuk menjawab permasalahan yang ada.

Analisis Kinerja Realisasi Anggaran Pendapatan dan Belanja Daerah dalam Mahsun (2014:152), terdiri atas:

1. Analisis Kinerja Realisasi Anggaran Pendapatan

a. Analisis Varians Anggaran Pendapatan : Selisih antara pendapatan dengan yang dianggarkan

b. Analisis Rasio Derajat Desentralisasi

c. Analisis Efisiensi Pajak Daerah

2. Analisis Kinerja Realisasi Anggaran Belanja

a. Analisis Varians Anggaran Belanja : Selisih antara realisasi belanja dengan anggaran

b. Analisis Keserasian Belanja :

1. Rasio Belanja Langsung 


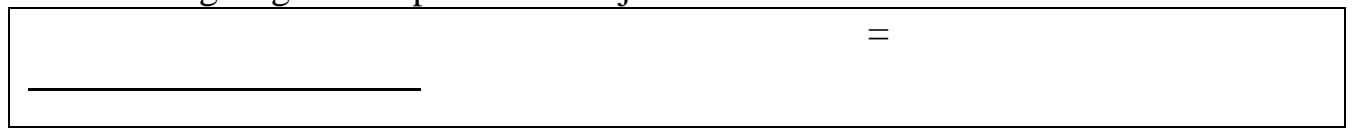

c. Analisis Rasio Efisiensi Belanja

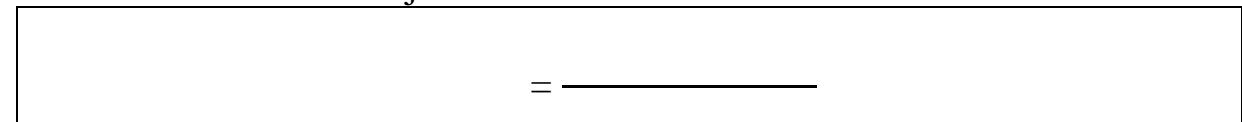

3. Potensi Pendapatan Asli Daerah

Lumikis (2015:6), Menyatakan dalam menghitung potensi pendapatan asli daerah dapat dilakukan dengan cara sebagai berikut;

1. Analisis Perbandingan Laporan Keuangan (comparative financial statement).

Analisis Perbandingan Laporan Keuangan (comparative financial statement) adalah metode dan teknik analisis dengan cara membandingkan laporan keuangan untuk dua periode atau lebih dengan menunjukkan:

a. Data absolut atau jumlah-jumlah dalam rupiah.

b. Kenaikan atau penurunan dalam jumlah rupiah

c. Kenaikan atau penurunan dalam persentase

d. Perbandingan yang dinyatakan dengan rasio

e. Persentase total

2. Analisis Historis Yang Bersifat Efektif dan Efisien

a. Menghitung Kenaikan Realisasi Tiap Tahun

\section{Keterangan:}

TK = Penerimaan pajak daerah/ retribusi daerah tahun yang bersangkutan

= Data realisasi/ penerimaan pajak daerah/ retribusi daerah tahun yang bersangkutan

$=$ Data realisasi/ penerimaan pajak daerah/retribusi daerah tahun sebelumnya

b. Menghitung rata-rata tingkat kenaikan realisasi penerimaan pajak daerah dan retribusi daerah Kabupaten Minahasa Utara

\section{Keterangan:}

$\times \mathrm{TK}=$ Rata-rata tingkat kenaikan realisasi

$\Sigma \mathrm{TK}=$ Jumlah kenaikan relative

$\mathrm{N} \quad=$ Jumlah Tahun

c. Menghitung Proyeksi Potensi Penerimaan Pajak Daerah dan Retribusi Daerah dengan menggunakan cara:

Keterangan:

$$
\text { TKR + Kenaikan Tarif) }+100 \%\} x
$$

$=$ Proyeksi penerimaan pajak daerah/ retribusi daerah pada tahun bersangkutan

= Penerimaan atau realisasi pajak daerah/retribusi daerah satu tahun sebelumnya. 


\section{HASIL PENELITIAN DAN PEMBAHASAN}

\section{Hasil Penelitian}

Analisis Kinerja Realisasi Anggaran Pendapatan

1. Analisis Varians Pendapatan

Tabel 4.2

Analisis Varians Anggaran Pendapatan

Tahun 2011-2015

\begin{tabular}{cccc}
\hline Tahun & Anggaran $(\mathbf{R p )}$ & Realisasi(Rp) & Selisih \\
\hline 2011 & 482.959 .390 .476 & 490.709 .686 .721 & 7.750 .296 .245 \\
\hline 2012 & 529.403 .435 .771 & 542.682 .298 .121 & 13.278 .862 .350 \\
\hline 2013 & $584.385 .630 .821,20$ & 589.388 .340 .723 & $5.002 .709 .901,8$ \\
\hline 2014 & 646.889 .321 .701 & 664.013 .622 .605 & 17.124 .300 .904 \\
\hline 2015 & 817.816 .583 .027 & 814.425 .493 .546 & -3.391 .089 .418 \\
\hline \multicolumn{5}{c}{ Rata-rata } & $\mathbf{7 . 9 5 3 . 0 1 5 . 9 9 6 , 5 6}$ \\
\hline
\end{tabular}

Sumber: Data diolah tahun 2016

2. Analisis Rasio Derajat Desentralisasi

Tabel 4.3

Analisis Rasio Derajat Desentralisasi

Tahun 2011-2015

\begin{tabular}{cccc}
\hline Tahun & PAD (Rp) & Pendapatan Daerah $(\mathbf{R p})$ & $\mathbf{( \% )}$ \\
\hline 2011 & 15.720 .419 .227 & 490.709 .686 .721 & 3,20 \\
\hline 2012 & 18.975 .761 .465 & 542.682 .298 .121 & 3,49 \\
\hline 2013 & 36.090 .808 .546 & 589.388 .340 .723 & 6,12 \\
\hline 2014 & 49.283 .471 .770 & 664.013 .622 .605 & 7,42 \\
\hline 2015 & 56.487 .375 .508 & 817.816 .583 .027 & 6,90 \\
\hline \multicolumn{5}{c}{ Rata-rata } \\
\hline
\end{tabular}

Sumber: Data diolah tahun 2016

3. Analisis Rasio Efektivitas Pajak Daerah

Tabel 4.4

Analisis Rasio Efektivitas Pajak Daerah

Tahun 2011-2015

\begin{tabular}{cccc}
\hline \multirow{2}{*}{ Tahun } & \multicolumn{2}{c}{ Pajak Daerah } & \multirow{2}{*}{ (\%) } \\
\cline { 2 - 3 } & Rencana (Rp) & Realisasi(Rp) & \\
\hline 2011 & 4.799 .097 .016 & 5.274 .087 .578 & 109,90 \\
\hline 2012 & 8.182 .435 .000 & 10.710 .695 .408 & 130,90 \\
\hline 2013 & $10.691 .313 .997,20$ & 11.256 .896 .212 & 105,29 \\
\hline 2014 & 18.025 .000 .000 & 20.652 .981 .106 & 114,61 \\
\hline 2015 & 22.925 .000 .000 & 25.260 .149 .479 & 110,19 \\
\hline \multicolumn{5}{c}{ Rata-rata } & $\mathbf{1 1 4 , 1 7}$ \\
\hline
\end{tabular}

Sumber: Data diolah tahun 2016 
Analisis Kinerja Realisasi Anggaran Belanja

1. Analisis Varians Anggaran Belanja

Tabel 4.5

Analisis Varians Anggaran Belanja

Tahun 2011-2015

\begin{tabular}{cccc}
\hline Tahun & Anggaran $(\mathbf{R p )}$ & Realisasi (Rp) & Selisih \\
\hline 2011 & 517.473 .819 .422 & 466.512 .840 .002 & 50.960 .979 .420 \\
\hline 2012 & 586.148 .542 .736 & 528.811 .677 .569 & 57.336 .865 .167 \\
\hline 2013 & 654.871 .048 .498 .2 & 591.135 .454 .245 & 63.735 .594 .253 .2 \\
\hline 2014 & 714.823 .062 .126 & 654.834 .370 .376 & 59.988 .691 .750 \\
\hline 2015 & 817.900 .482 .719 & 737.749 .807 .224 & 80.150 .675 .495 \\
\hline \multicolumn{4}{c}{ Rata-rata } \\
\hline \multicolumn{4}{c}{ Sumber: Data diolah tahun 2016 }
\end{tabular}

2. Analisis Keserasian Belanja : Rasio Belanja Langsung dan Belanja Tidak Langsung.

Tabel 4.6

Belanja Tidak Langsung

Tahun 2011-2015

\begin{tabular}{cccc}
\hline Tahun & Belanja Langsung $(\mathbf{R p})$ & Total Belanja $(\mathbf{R p})$ & $\mathbf{( \% )}$ \\
\hline 2011 & 96.971 .225 .501 & 466.512 .840 .002 & 20,78 \\
\hline 2012 & 114.654 .479 .751 & 528.811 .677 .569 & 21,68 \\
\hline 2013 & 139.039 .608 .186 & 591.135 .454 .245 & 23,52 \\
\hline 2014 & 148.072 .839 .603 & 654.834 .370 .376 & 22,61 \\
\hline 2015 & 169.800 .811 .692 & 737.749 .807 .224 & 23,01 \\
\hline \multicolumn{5}{c}{ Rata-rata } \\
\hline
\end{tabular}

Sumber: Data diolah tahun 2016

Tabel 4.7

Belanja Langsung

Tahun 2011-2015

\begin{tabular}{cccc}
\hline Tahun & Belanja Tidak Langsung $(\mathbf{R p})$ & Total Belanja $(\mathbf{R p )}$ & $\mathbf{( \% )}$ \\
\hline 2011 & 369.448 .364 .501 & 466.512 .840 .002 & 79,19 \\
\hline 2012 & 411.239 .564 .654 & 528.811 .677 .569 & 77,76 \\
\hline 2013 & 451.986 .878 .059 & 591.135 .454 .245 & 76,46 \\
\hline 2014 & 506.488 .030 .773 & 654.834 .370 .376 & 77,34 \\
\hline 2015 & 567.552 .144 .532 & 737.749 .807 .224 & 76,93 \\
\hline \multicolumn{5}{c}{ Rata-rata } & $\mathbf{7 7 , 5 3}$ \\
\hline
\end{tabular}

Sumber: Data diolah tahun 2016

3. Rasio Efesiensi Belanja

Tabel 4.8

Efisiensi Belanja

Tahun 2011-2015

\begin{tabular}{cccc}
\hline Tahun & Anggaran $(\mathbf{R p )}$ & Realisasi (Rp) & $\mathbf{( \% )}$ \\
\hline 2011 & 517.473 .819 .422 & 466.512 .840 .002 & 90,15 \\
\hline 2012 & 586.148 .542 .736 & 528.811 .677 .569 & 90,22 \\
\hline 2013 & 654.871 .048 .498 .2 & 591.135 .454 .245 & 90,26 \\
\hline 2014 & 714.823 .062 .126 & 654.834 .370 .376 & 91,60 \\
\hline 2015 & 817.900 .482 .719 & 737.749 .807 .224 & 90,20 \\
\hline \multicolumn{5}{c}{ Rata-rata } & $\mathbf{9 0 , 4 8}$ \\
\hline
\end{tabular}

Sumber: Data diolah tahun 2016 


\section{Menghitung Potensi Pendapatan Asli Daerah}

1. Potensi Penerimaan Pajak Daerah Kabupaten Minahasa Utara

Berdasarkan hasil penelitian dan data yang telah didapat, penulis akan menyajikan hasil Penerimaan Pajak Daerah dengan mengevaluasi data historis realisasi Pajak Daerah Kabupaten Minahasa Utara untuk melihat pertumbuhan tahun anggaran tahun 2011-2015.

\section{Tabel 4.9}

Data Pertumbuhan Pajak Daerah Kabupaten Minahasa Utara Tahun 2011-2015

\begin{tabular}{cccc}
\hline Tahun & Realisasi (Rp) & $\begin{array}{c}\text { Growth/ } \\
\text { Pertumbuhan }\end{array}$ & $\mathbf{( \% )}$ \\
\hline 2011 & 5.274 .087 .578 & - & - \\
\hline 2012 & 10.710 .695 .408 & 5.436 .607 .830 & 103,08 \\
\hline 2013 & 11.256 .896 .212 & 546.200 .806 & 5,1 \\
\hline 2014 & 20.657 .981 .106 & 9.401 .084 .895 & 83,51 \\
\hline 2015 & 25.260 .149 .479 & 4.602 .168 .370 & 22,27 \\
\hline \multicolumn{4}{c}{ Sumber: Data diolah tahun 2016 }
\end{tabular}

Dari perhitungan diatas, diketahui bahwa realisasi pertumbuhan penerimaan pajak daerah mengalami kenaikan $103,08 \%$ pada tahun 2012. Kemudian mengalami penurunan 5,1\% pada tahun 2013. Selanjutnya pada tahun 2014 mengalami kenaikan sebesar 83,51\%. Sedangkan pada tahun 2015 mengalami penurunan $22,27 \%$.

Dari hasil diatas kita dapat menghitung rata-rata tingkat pertumbuhan real (TKR) Pajak Daerah yaitu:

Jadi rata-rata tingkat kenaikan potensi pajak daerah adalah sebesar $42,78 \%$

Tabel 4.10

Potensi Penerimaan Pajak Daerah

2016-2020

\begin{tabular}{cccc}
\hline Tahun & Pajak Daerah (Rp) & $\begin{array}{c}\text { Growth/ } \\
\text { Pertumbuhan }\end{array}$ & (\%) \\
\hline 2016 & $36.066 .441 .426,11$ & $10.806 .291 .945,11$ & 42,78 \\
\hline 2017 & $51.495 .665 .068,19$ & $15.429 .223 .642,08$ & 42,78 \\
\hline 2018 & $73.525 .510 .584,36$ & $22.029 .845 .516,17$ & 42,78 \\
\hline 2019 & $104.979 .724 .012,33$ & $31.454 .213 .427,98$ & 42,78 \\
\hline 2020 & 149.869 .054 .000 & $44.889 .329 .987,67$ & 42,78 \\
\hline
\end{tabular}

Sumber: Data diolah tahun 2016

2. Potensi Penerimaan Retribusi Daerah Kabupaten Minahasa Utara

Berdasarkan hasil penelitian dan data yang telah didapat, penulis akan menyajikan hasil Penerimaan Pajak Daerah dengan mengevaluasi data historis realisasi Retribusi Daerah Kabupaten Minahasa Utara untuk melihat pertumbuhan tahun anggaran tahun 2011-2015. 
Tabel 4.11

Data Pertumbuhan Retribusi Daerah Kabupaten Minahasa Utara

Tahun 2011-2015

\begin{tabular}{cccc}
\hline Tahun & Realisasi (Rp) & $\begin{array}{c}\text { Growth/ } \\
\text { Pertumbuhan }\end{array}$ & $\mathbf{( \% )}$ \\
\hline 2011 & 2.887 .140 .079 & - & \\
\hline 2012 & 4.657 .328 .991 & 1.770 .188 .912 & 61,31 \\
\hline 2013 & 11.750 .512 .282 & 7.093 .183 .291 & 152,30 \\
\hline 2014 & 8.514 .091 .490 & $(3.236 .420 .792)$ & $-27,54$ \\
\hline 2015 & 8.578 .223 .571 & 64.132 .081 & 0.75 \\
\hline
\end{tabular}

Sumber: Data diolah tahun 2016

Dari perhitungan diatas, diketahui bahwa realisasi pertumbuhan penerimaan pajak daerah mengalami kenaikan 61,31\% pada tahun 2012. Kemudian pada tahun 2013 juga mengalami kenaikan $152,30 \%$. Selanjutnya pada tahun 2014 mengalami penurunan sebesar $-27,54 \%$. Pada tahun 2015 mengalami kenaikan $0,75 \%$.

Dari hasil diatas kita dapat menghitung rata-rata tingkat pertumbuhan real (TKR) Pajak Daerah yaitu:

Jadi rata-rata tingkat kenaikan potensi retribusi daerah adalah sebesar 37,36\%

Tabel 4.12

Potensi Penerimaan Retribusi Daerah

Tahun 2016-2020

\begin{tabular}{cccc}
\hline Tahun & Retribusi Daerah (Rp) & $\begin{array}{c}\text { Growth/ } \\
\text { Pertumbuhan }\end{array}$ & (\%) \\
\hline 2016 & $11.783 .047 .897,12$ & $3.204 .824 .326,12$ & 37,36 \\
\hline 2017 & $16.185 .194 .591,48$ & $4.402 .146 .694,36$ & 37,36 \\
\hline 2018 & $22.231 .983 .290,85$ & $6.046 .788 .699,37$ & 37,36 \\
\hline 2019 & $30.537 .852 .248,31$ & $8.305 .868 .957,46$ & 37,36 \\
\hline 2020 & 41.946 .793 .848 .270 & $11.408 .941 .599,96$ & 37,36 \\
\hline
\end{tabular}

Sumber: Data diolah tahun 2016

\section{Pembahasan}

Berdasarkan hasil penelitian yang dilakukan maka dapat diketahui bahwa pembangunan daerah dapat berjalan dengan baik sesuai dengan prosedur yang telah ditetapkan oleh pemerintah daerah. Kepala daerah (Bupati) memegang kekuasaan umum dalam mengelola daerah. Hal ini dikarenakan kepala daerah mempunyai wewenang menyelenggarakan keseluruhan pengelolaan keuangan daerah dan mempunyai kewajiban menyampaikan pertanggung jawaban atas pelaksanaan kewenangan tersebut kepada DPRD.

\section{Kinerja Realisasi Anggaran Pendapatan Daerah}

1. Analisis Varians Anggaran Pendapatan

Analisis varians anggaran pendapaan dilakukan dengan cara menghitung selisih antara pendapatan dengan yang di anggarkan. Biasanya selisih anggaran sudah di informasikan dalam laporan realisasi anggaran yang disajikan oleh pemerintah daerah.Informasi selisih anggaran tersebut sangat membantu pengguna laporan dalam memahami dan menganalisis kinerja pendapatan. Rata-rata pendapatan pada tahun 2011-2015 sebesar Rp. 7.953.015.996,56.

2. Analisis Rasio Derajat Desentralisasi

Rasio ini menunjukan kewenangan dan tanggung jawab yang diberikan pemerintah pusat kepada pemerintah daerah untuk menggali dan mengelolah pendapatan. Semakin tinggi PAD, maka semakin tinggi kemampuan pemerintah daerah dalam penyelenggaraan desentralisasi. Dari perhitungan kinerja pendapatan pada table 4.3 terlihat bahwa derajat desentralisasi Kabupaten Minahasa Utara tahun 2011-2015 dapat dikatakan sangat rendah yaitu dengan rata-rata 5,42\%. 
3. Analisis Rasio Efektivitas Pajak Daerah

Rasio ini mengukur kemampuan pemerintah daerah dalam menghasilkan pendapatan dari pajak daerah.Efektivitas (hasil guna) adalah ukuran keberhasilan suatu organisasi dalam usaha mencapai tujuan organisasi yang telah ditetapkan.Efektivitas merupakan perbandingan outcome dan output. Hasil perhitungan pada table 4.4 rata-rata efektivitas dalam merealisasikan pajak daerah pemerintah kabupaten Minahasa Utara pada tahun2011-2015 memiliki rata-rata sebesar 114,17\%.

\section{Realisasi Anggaran Belanja Daerah}

1. Analisis Varians Anggaran Belanja

Analisisis varians memberikan informasi tentang perbedaan atau selisis antara realisasi belanja dan anggaran. Pemerintah daerah dapat dinilai baik kinerja belanjanya tidak melebihi target yang telah ditetapkan. Sebaliknya jika realisasi belanja lebih besar dari jumlah yang dianggarkan maka hal itu mengidentifikasikan adanya kinerja belanja yang kurang baik. Dari hasil penelitian yang dapat dilihat pada table 4.5 bahwa belanja yang dilakukan tidak melebihi target yang ditetapkan. Dengan kata lain pemerintah Kabupaten Minahasa Utara dapat mengendalikan anggaran belanja sehingga mendapatkan SILPA surplus (sisa lebih perhitungan anggaran) dengan rata-rata pada tahun 2011-2015 sebesar Rp. 62.434.561.217,04

2. Analisis Keserasian Belanja

Analisis varians merupakan analisis terhadap perbedaan atau selisih antara realisasi belanja dengan anggaran. Berdasarkan laporan realisasi anggaran yang disajikan, pembaca laporan dapat mengetahui secara langsung besarnya varians anggaran belanja dengan realisasinya yang bisa dinyatakan dalam bentuk nilai nominalnya atau presentasenya. Dari table 4.6 dan 4.7 dapat dilihat bahwa tahun 2011-2015 sebagian besar dana yang dimiliki pemerintah dialokasikan untuk belanja tidak langsung sehingga rasio belanja langsung relatif kecil dibandingkan rasio belanja tidak langsung. Rata-rata rasio untuk belanja langsung yaitu sebesar 77,53\% sedangkan untuk belanja tidak langsung yaitu $23,32 \%$.

3. Rasio Efisiensi Belanja

Rasio ini digunakan untuk mengukur tingkat penghematan anggaran yang dilakukan pemerintah. Efisiensi berhubungan dengan metode operasi. Proses kegiatan operasional dapat dikatakan efisien apabila suatu produk atau hasil karya tertentu mempergunakan sumber daya dan dana yang serendah rendahnya. Dari table 4.8 terlihat bahwa pemerintah Kabupaten Minahasa Utara telah melakukan efisiensi belanja yang dibuktikan dengan rasio efisensi pada rata-rata tahun 2011-2015 berada dibawah 100\% yaitu 90,48\%. Dapat dikatakan bahwa pemerintah kabupaten Minahasa Utara dapat mengendalikan belanja daerah dari target yang telah ditetapkan sebelumnya dengan tidak mengurangi tujuan dan sasaran dari program yang telah direncanakan dari awal.

\section{Potensi Pendapatan Asli Daerah}

Analisis Perbandingan Laporan Keuangan (comparative financial statement) adalah metode dan teknik analisis dengan cara membandingkan laporan keuangan untuk dua periode atau lebih dengan menunjukkan, data absolut atau jumlah-jumlah dalam rupiah, kenaikan atau penurunan dalam jumlah rupiah, kenaikan atau penurunan dalam persentase, perbandingan yang dinyatakan dengan rasio, persentase total. Selanjutnya dari hasil analisis yang didapatkan dikembangkan untuk menghitung potensi pendapatan asli daerah lima tahun yang akan datang dari rata-rata pertumbuhan lima tahun sebelumnya dengan menggunakan analisis rasio keuangan pertumbuhan.

1. PotensiPendapatan Pajak Daerah

Berdasarkan perhitungan pada table 4.12 diketahui bahwa realisasi pertumbuhan penerimaan pajak daerah mengalami kenaikan 103,08\% pada tahun 2012. Kemudian mengalami penurunan 5,1\% pada tahun 2013. Selanjutnya pada tahun 2014 mengalami kenaikan sebesar 83,51\%. Sedangkan pada tahun 2015 mengalami penurunan 22,27\%. Dengan rata-rata pertumbuhan penerimaan pajak sebesar $42,78 \%$. Dari rata-rata pertumbuhan penerimaan pajak yang ada Potensi penerimaan pajak daerah Kabupaten Minahasa Utara pada lima tahun mendatang yaitu pada tahun 2016-2020 yang mana tahun 2016 sebesar Rp.11.783.047.897,12, tahun 2017 sebesar Rp. 16.185.194.591,48, tahun 2018 sebesar Rp.22.231.983.290,85, tahun 2019 Rp. 30.537.852.248,31 dan tahun 2020 sebesar Rp. 41.946.793.848.270.

2. Potensi Retribusi Daerah 
Dari pada table 4.14 diketahui bahwa realisasi pertumbuhan penerimaan pajak daerah mengalami kenaikan 61,31\% pada tahun 2012. Kemudian pada ahun 2013 juga mengalami kenaikan $152,30 \%$. Selanjutnya pada tahun 2014 mengalami penurunan sebesar -27,54\%. Pada tahun 2015 mengalami kenaikan 0,75\%. Dengan rata-rata pertumbuhan penerimaan retribusi daerah sebesar 37,36\%. Dari rata-rata pertumbuhan penerimaan retribusi daerah yang ada,potensi penerimaan retribusi daerah Kabupaten Minahasa Utara pada lima tahun mendatang tahun 20162020 yang mana pada tahun2016 sebesar Rp.11.783.047.897,12, tahun 2017 sebesar Rp. 16.185.194.591,48, tahun 2018 sebesar Rp.22.231.983.290,85, tahun 2019 Rp. 30.537.852.248,31 dan tahun 2020 Rp. 41.946.793.848.270.

\section{Kesimpulan}

\section{PENUTUP}

Kesimpulan dalam penelitian ini:

1. Anggaran pendapatan belanja daerah pemerintah kabupaten Minahasa Utara dilihat dari sisi pendapatan dengan menggunakan analisis varians tahun 2011-2015 dapat dikatakan baik karena rata-rata pendapatan mencapai target sebesar Rp. 7.953.015.996,56

2. Anggaran pendapatan belanja daerah pemerintah kabupaten Minahasa Utara dilihat dari sisi pendapatan dengan menggunakan analisis rasio derajat desentralisasi dapat dikatakan masih rendah, dengan tingkat derajat desentralisasi pada tahun 2011-2015 rata-rata sebesar 5,42\%.

3. Anggaran pendapatan belanja daerah pemerintah kabupaten Minahasa Utara dilihat dari sisi pendapatan dengan menggunakan analisis efektivitas pajak daerah dalam hal ini dinas pendapatan daerah sangat efektif dalam merealisasikan pajak daerah yang direncanakan dengan rata-rata pada tahun 2011-2015 sebesar 114,17\%.

4. Kinerja belanja pemerintah kabupaten Minahasa Utara dilihat dari analisis varians secara umum dapat mengendalikan anggaran belanja sehingga mendapatkan SILPA surplus (sisa lebih perhitungan anggaran) dengan rata-rata sebesar Rp. 62.434.561.217,04selama tahun 2011-2015.

5. Pemerintah Kabupaten Minahasa Utara pada tahun 2011-2015, menggunakan sebagian besar dana yang dimiliki untuk belanja tidak langsung rata-rata sebesar $77,53 \%$ sedangkan untuk belanja langsung rata-rata sebesar $22,32 \%$.

6. Tingkat efesiensi pemerintah kabupaten Minahasa Utara tahun anggaran 2011-2015 dilihat dari analisis efesiensi belanja dapat dikatakan efisien yaitu rata-rata sebesar 90,48\%.

7. Potensi pendapatan asli daerah kabupaten Minahasa Utara dilihat dari segi penerimaan Pajak daerah dengan tingkat petumbuhan untuk lima tahun mendatang tahun 2016-2020 akan terjadi kenaikan sebesar $42,78 \%$ sedangkan dari segi retribusi daerah akan terjadi kenaikan sebesar $37,36 \%$. Sehingga dapat dilihat bahwa pajak daerah lebih berpotensi dalam meningkatkan pendapatan asli daerah kabupaten Minahasa Utara.

\section{Saran}

Saran yang diberikan:

1. Pemerintah kabupaten Minahasa Utara harus lebih berusaha lagi untuk dapat meningkatkan pendapatan asli daerah (PAD) melalui pengembangan potensi-potensi yang sudah ada dan juga menggali potensi-potensi yang baru

2. Pemerintah kabupaten Minahasa Utara lebih khususnya Dinas Pendapatan agar dapat menigkatkan fungsi kontrol sehingga dapat memudahkan untuk perhitungan potensi daerah untuk meningkatkan Pendapatan Asli Daerah yang lebih optimal.

3. Bagi peneliti selanjutnya disarankan untuk manambah rasio-rasio keuangan yang dapat digunakan dalam menganalisis kinerja pemerintah daerah. Dan juga disanrankan untuk menambah metode analisis data untuk menghitung potensi Pendapatan Asli Daerah pemerintah. 


\section{DAFTAR PUSTAKA}

Lumikis Riri, 2015. Analisis Potensi Penerimaan Pajak Daerah Dan Retribusi Daerah Terhadap Peeningkatan Pendapatan Asli Daerah (PAD) Di Seluruh Kabupaten/ Kota Provinsi Maluku Utara.Program magister Akuntansi (MAKSI) Fakultas Ekonomi dan Bisnis Universitas Sam Ratulangi Manado.

Mahmudi, 2011. Akuntansi Sektor Publik. Yogyakarta:UII Press.

Mardiasmo, 2009.Akuntansi Sektor Publik. Andi. Yogyakarta

Murdiati Sri, 2010. Analisis Potensi Pendapatan Asli Daerah (PAD). Fakultas Ekonomi Universitas Pancasakti Tegal.

Mahsun Mohamad, 2013. Pengukuran Kinerja Sektor Publik. BPFE. Yogyakarta

Mahsun. Moh, Sulistyowati Firma dan Purwanugraha Heribertus. 2015. Akuntansi Sektor Publik. BPFE-Yogyakarta.

Norma Komalig, 2014. Potensi Peningkatatan Pendapatan Asli Daerah Di Kabupaten Minahasa Tenggar. Pasca Sarjana Universitas Sam Ratulangi Manado.

Peraturan Menteri Dalam Negeri Republik Indonesia No 21 Tahun 2011 tentang Perubahan Kedua Atas Peraturan Menteri Dalam Negeri Nomor 13 Tahun 2006 Tentang Pedoman Pengelolaan Keuangan Daerah.

Peraturan Pemerintah No. 71 Tahun 2010 tentang Standar Akuntansi Pemerintah

Undang-undang Republik Indonesia No. 17 tahun 2003 tentang Keuangan Negara.

Undang-undang Republik Indonesia No. 32 tahun 2004 tentang Pemerintah Daerah. 